\section{Evaluation of freezing point in milk from buffalos reared in Calabria, Italy}

\author{
Carlotta Ceniti, Domenico Britti, \\ Francesca Trimboli, \\ Valeria Maria Morittu, Vincenzo \\ Lopreiato, Nicola Costanzo \\ Department of Health Science and \\ Interdepartmental Services Centre of \\ Veterinary for Human and Animal \\ Health, Magna Gracia University of \\ Catanzaro, Italy
}

\begin{abstract}
Evaluation of freezing point is one of the most common technique used to detect milk adulteration such as addition of external water to increase volume. The aim of this study was to evaluate the freezing point of buffalo milk using infrared spectroscopy and to assess how it is influenced by other milk components. A total of 361 individual buffalo milk samples were collected monthly from March to August of 2017 in a dairy farm in Catanzaro district, Italy. Samples were tested for freezing point, urea, acetone and beta-hydroxybutyrate, percent of fat, protein, lactose, casein, by Fourier Transformed Spectroscopy. The $\mathrm{pH}$ and daily milk production were also recorded. Freezing point ranged from $-0.574^{\circ} \mathrm{C}$ to $0.512^{\circ} \mathrm{C}$ and the mean values was $-0.545^{\circ} \mathrm{C}$ \pm 0.010 . According to lactation stage, freezing point decreased until 210 days post-partum reaching the minimum value of $-0.550^{\circ} \mathrm{C}$, then it slightly increased during lactation; according to sampling month the highest and lowest values were recorded in August and June, respectively. A positive correlation between freezing point and lactose content were evidenced $(\mathrm{r}=0.1806$, $\mathrm{P}<0.05)$. Moreover, a faintly positive correlation was also found between freezing point and beta-idroxibutirrate $(r=0.0869$, $\mathrm{P}<0.05)$ and acetone $(\mathrm{r}=0.0096, \mathrm{P}<0.05)$, whereas a negative correlation with fat $(\mathrm{r}=-0.2356, \mathrm{P}<0.05)$, protein $(\mathrm{r}=-0.1855$, $\mathrm{P}<0.05)$, casein $(\mathrm{r}=-0.2127, \mathrm{P}<0.05)$ and urea $(\mathrm{r}=-0.1229, \mathrm{P}<0.05)$ was evidenced.
\end{abstract}

\section{Introduction}

Buffalo milk, the second most produced milk after bovine milk, accounting the $14 \%$ of global milk production in 2014 (FAOSTAT, 2017), is of great importance due to its nutritional and technological aspects; it differs from cow milk in its higher concen- tration of protein, fat, lactose and ash (Ahmad et al., 2013, 2008). Interest in buffalo milk is growing globally due to high milk solids that make it ideal for processing into dairy products (Zicarelli, 2004; Ahmad et al., 2013). In Italy, almost all buffalo milk is transformed into mozzarella cheese. The limited availability and high price, about three times that of cow milk, make it and its dairy products an attractive target of frauds and adulterations. Buffalo milk adulteration typically involves dilution and/or addition of inexpensive, low-quality, and sometimes dangerous products in order to increase the volume, mask inferior quality or replace the natural substances in milk for economic gain; the simplest case is addition of water to increase the volume (Nascimento et al., 2017). Freezing point (FP) monitoring is actually the fastest way to evaluate water adding to milk and is also used for calculating the price of raw milk purchased and processed into dairy products (IDF, 2006). Actually, data regarding the mean value of freezing point in buffalo milk are limited. In Italy, Pesce et al. (2016) shown a FP mean value of $-0.536{ }^{\circ} \mathrm{C}$ whereas, in India, Prajapati et al. (2007) found a FP ranging between $-0.584{ }^{\circ} \mathrm{C}$ and $-0.532{ }^{\circ} \mathrm{C}$ with a mean value of $-0.558^{\circ} \mathrm{C}$.

Many factors may affect the FP making difficult to establish a reference value. Until 2004, the maximum allowed FP of both raw and heat-treated drinking cow's milk was $\leq$ $0.520^{\circ} \mathrm{C}$ in compliance with EU legislation (Council 92/46 92/47/EEC Directive of 16 June 1992). Actually, according to Regulation (EC) $n^{\circ}$ 1308/2013 (European Parliament and European Council, 2013), the FP of drinking milk must be close to the mean FP recorded in raw milk in the original area of production. However, the actual legislation makes no mention of the freezing point of buffalo, which remains an important quality index of raw milk. Therefore, it becomes important to establish a mean value for FP linked to the production area that can be used in case of doubt of water addition.

The aim of our study was to provide indication of FP values in a population of buffaloes reared in Calabria region, Italy and to monitor how it changes according to lactation stage, seasons (spring and summer) and how it is influenced by the principal milk components.

\section{Materials and Methods}

Individual milk samples were collected from a dairy farm located in Calabria region, Italy. For this aim, a total of 74 Italian Mediterranean buffaloes (Bubalus
Correspondence: Nicola Costanzo Department of Health Sciences, Magna Græcia University, Viale Europa, Loc. Germaneto, Edificio delle Bioscienze 88100 , Catanzaro (CZ), Italy.

Tel. +39.0961.3694203

E-mail: costanzo.nic@unicz.it

Key words: Freezing point, infrared spectroscopy, buffalo, milk.

Contributions: the authors contributed equally.

Conflict of interest: the authors declare no potential conflict of interest.

Funding: none.

Received for publication: 22 October 2018. Revision received: 8 January 2019.

Accepted for publication: 8 February 2019.

This work is licensed under a Creative Commons Attribution-NonCommercial 4.0 International License (CC BY-NC 4.0).

CCopyright C. Ceniti et al., 2019

Licensee PAGEPress, Italy

Italian Journal of Food Safety 2019; 8:7895

doi:10.4081/ijfs.2019.7895

bubalis) were randomly selected and monthly sampled from March to August 2017. All animals enrolled in the study were clinically health as evaluated on rectal temperature, heart rate, respiratory profile, appetite and fecal consistency.

At the time of first sampling, 13 animals were at the first lactation and the remaining were multiparous (from $2^{\text {nd }}$ up to $8^{\text {nd }}$ lactation), in addition the animals were in different stages of lactation (125 \pm 83 days in milk). A total of 362 milk samples were collected and the daily production (liters) was also recorded for each animal during the experimental period.

Samples were collected through manual milking: teats were cleaned with water and disinfected with $70 \%$ alcohol and carefully dried to avoid the presence of water residues prior to milk samples collection. The first 3 jets of milk were discarded and approximately $50 \mathrm{~mL}$ milk was pooled from the 4 mammary glands using sterilized polypropylene tubes and subsequently stored at $4^{\circ} \mathrm{C}$ until analysis that occurred within the same day of sampling.

Before analysis, the milk samples were gently mixed and heated to $40^{\circ} \mathrm{C}$ for 15 minutes. All samples were analyzed for freezing point $\left({ }^{\circ} \mathrm{C}\right)$, fat $(\%)$, protein $(\%)$, lactose $(\%)$, casein $(\%)$, urea $(\mathrm{mg} / \mathrm{dL})$, betaidroxibutirrate $(\mathrm{mM})$ and acetone $(\mathrm{mM})$ using a MilkoScan FT plus infrared analyzer (Fossomatic; Foss Electric, Hillerød, 
Denmark). The MilkoScan FT is based on Fourier transform infrared technology that exploits the vibration of various chemical groups at specific wavelengths in the midinfrared region of the spectrum (from 1000 to $5000 \mathrm{~cm}^{-1}$ ).

The $\mathrm{pH}$ of milk was measured at room temperature using a portable $\mathrm{pH}$ instrument (Orion Research Inc., Boston, MA).

Statistical analysis was performed using GraphPad Prism version 7.00 for Windows (GraphPad Software, La Jolla, CA, USA). Mean, standard deviation, minimum and maximum values for each parameter analyzed were calculated. The milk samples were divided into 4 groups, according to lactation stage. Group I: milk samples up to 70 days in milk (DIM); group II: from 71 to 140 DIM; group III: from 141 to 210 DIM; group IV: from 210 to 280 DIM and group $\mathrm{V}$ which included animals from the $280^{\text {st }}$ DIM to the end of lactation. Moreover, milk samples were divided also according to sampling month in 6 groups from March to August. In order to assess if the differences of FP values among the different lactation stages or sampling months exist, KruskalWallis one-way analysis of variance
(ANOVA) on rank with Dunn's Method multiple comparison post-test was applied. A P-value less than 0.05 was considered significant.

The Spearman's rank correlation coefficient was also used to assess correlation between FP and the other milk parameters and was considered statistical significative a $\mathrm{P}$ value $<0.05$.

\section{Results}

FP values were not normally distributed; therefore, the reference ranges were constructed using median and 2.5\% - 97.5\% intervals and reported in Table 1.

The mean, standard deviation, minimum and maximum values of milk production, fat, protein, lactose, casein, urea, acetone, beta-idroxibutirrate content and $\mathrm{pH}$ results are reported in Table 2 .

Table 3 shows FP according to days in milk (DIM): the FP value decreases $(\mathrm{P}<0.001)$ with the progress of lactation stage, in particular until to 210 DIM and then remains constant.
Table 4 reports FP of buffalo milk samples according to months: the median value of FP for the samples collected in June was lower respect to other months with the exception of July $(\mathrm{P}<0.05)$. Moreover, the median value recorded in August was the highest and significantly differed $(\mathrm{P}<0.05)$ from milk samples collected in May, June and July. FP positively correlated with milk production $(\mathrm{r}=0.2345)$, lactose $(\mathrm{r}=0.1806)$, beta-idroxibutirrate $(\mathrm{r}=0.0869)$ and acetone $(\mathrm{r}=0.0096)$ contents whereas showed negative correlation with fat $(\mathrm{r}=-0.2356)$, protein $(\mathrm{r}=-0.1855)$, casein $(\mathrm{r}=-0.2127)$ and urea $(\mathrm{r}=-0.1229)$ contents.

Table 1. Freezing point values descriptive statistic.

\begin{tabular}{lc} 
Number of values & 362 \\
Minimum & $-0.574^{\circ} \mathrm{C}$ \\
Median & $-0.546^{\circ} \mathrm{C}$ \\
\hline Maximum & $-0.512^{\circ} \mathrm{C}$ \\
$2.5 \%$ Percentile & $-0.564^{\circ} \mathrm{C}$ \\
\hline $97.5 \%$ Percentile & $-0.522^{\circ} \mathrm{C}$ \\
Mean & $-0.546^{\circ} \mathrm{C}$ \\
\hline Std. Dev. & $0.010^{\circ} \mathrm{C}$
\end{tabular}

Table 2. Mean, standard deviation, minimum and maximum of milk production, fat, protein, lactose, casein, urea, acetone, beta-idroxibutirrate content and pH values of 362 buffalo milk samples.

\begin{tabular}{lccccccccc}
$\mathbb{N}=362$ & Milk Production (L) & Fat (\%) & Proteins (\%) & Lactose (\%) Casein (\%) & Urea (mg/dL) & Acetone (mM) & BHBB (mil) & pH \\
Mean & 10.21 & 8.41 & 4.65 & 4.48 & 3.77 & 48.31 & 0.20 & 0.04 & 6.73 \\
Std dev & 3.52 & 1.59 & 0.52 & 0.38 & 0.49 & 10.40 & 0.13 & 0.07 & 0.12 \\
\hline Minimun & 1.5 & 3.39 & 2.06 & 1.96 & 1.64 & 19.56 & 0.00 & 0.00 & 6.40 \\
Maximum & 19.8 & 13.10 & 6.10 & 5.54 & 5.82 & 77.70 & 0.83 & 1.05 & 7.30 \\
\hline
\end{tabular}

Table 3. Freezing point median values according to days in milk (DIM).

\begin{tabular}{llcll} 
DIM (day) & N. & Median $\left({ }^{\circ} \mathrm{C}\right)$ & $25 \%$ & $75 \%$ \\
Group 1 $(\leq 70)$ & 106 & $-0.542^{\mathrm{a}}$ & -0.546 & -0.536 \\
Group 2 $(70-140)$ & 126 & $-0.547^{\mathrm{b}}$ & -0.552 & -0.542 \\
\hline Group 3 $(141-210)$ & 75 & $-0.550^{\mathrm{bc}}$ & -0.557 & -0.542 \\
Group 4 (211-280) & 34 & $-0.546^{\text {bd }}$ & -0.556 & -0.542 \\
\hline Group 5 $(>280)$ & 21 & $-0.547^{\text {ab }}$ & -0.556 & -0.540 \\
\hline
\end{tabular}

Different superscript indicates significant differences $\mathrm{P}<0.05$; $\mathrm{n}=$ number of milk samples.

Table 4. Freezing point median values according to months.

\begin{tabular}{lccc} 
Months & N. & Median $\left({ }^{\circ} \mathbf{C}\right)$ & $25 \%$ \\
March & 51 & $-0.543^{\text {abcf }}$ & $-0,548$ \\
April & 57 & $-0.544^{\text {abcf }}$ & $-0,538$ \\
\hline May & 59 & $-0.547^{\text {abce }}$ & $-0,547$ \\
June & 59 & $-0.552^{\text {de }}$ & $-0,552$ \\
\hline July & 68 & $-0.548^{\text {cde }}$ & $-0,540$ \\
August & 68 & $-0.542^{\text {abf }}$ & $-0,557$ \\
\hline
\end{tabular}

Different superscript indicates significant differences $\mathrm{P}<0.05 ; \mathrm{n}=$ number of milk samples. 


\section{Discussion}

At our knowledge, this study is the first to determine FP of buffalo milk on individual samples and provides the first indication of a reference range in our region. The collection of individual milk samples bypasses the problem related to water presence in milk samples when milking machine or tank are not properly dried after cleaning. FP ranged between a minimum of $-0.574^{\circ} \mathrm{C}$ to a maximum of $-0.512^{\circ} \mathrm{C}$ with a mean value of $-0.545^{\circ} \mathrm{C}$.

The FP mean value here reported is lower than values reported by Pesce et al. (2016) who evidenced a mean value of $0.536^{\circ} \mathrm{C}$ in bulk tank buffalo milk collected in Campania region (Italy) and higher than values reported by Hofi et al., (1966) who evidenced a FP ranging from -0.552 to $0.558^{\circ} \mathrm{C}$. Differently, our results are very close to the results reported by KedzierskaMatysek et al. (2011) who found a mean FP value of $-0.544^{\circ} \mathrm{C}$ in Jersey milk, a cow breed having a milk protein and lactose content similar to buffalo milk.

It is well known that many factors affect the FP of milk such as milk components (Senevirathne et al., 2016), feed (Campanile et al., 1998), preservation (Radeljevic et al., 2012), thermal treatment (Zagorska et al., 2013), time of milking (Slaghuis, 2001), lactation stage (Potena et al., 2001), breed, year and period (Henno, 2008), but no one of the parameters investigated shown a strong correlation with FP. Indeed, whilst urea, protein, fat and casein were negative correlated with FP as reported by other authors in cow and ewe milk (Kedzierska-Matysek et al., 2011; Wiedemann et al., 1993) lactose, between milk components, showed the highest positive correlation value.

Additionally, our results demonstrated that FP was affected by lactation stage and evidenced a positive correlation with milk production: in agreement with Potena et al. (2001) and Senevirathne et al. (2016) who reported a significant correlation between FP and lactation stages in buffaloes and cows respectively, FP significantly decreased until to 210 DIM reaching the minimum median value. Moreover, as reported by Kędzierska-Matysek et al. (2011) in cow milk, we evidenced that FP fluctuated throughout the lactation stages: as lactation progressed the FP of the milk decreases coinciding with the increase of protein and fat contents and decrease of milk production.

Data obtained in the present study also demonstrate that FP significantly changes during the progression by spring to summer seasons reaching the maximum mean value in August. Literature data on the season as factor influencing the FP are limited and contradictory. Kędzierska-Matysek et al. (2011) did not evidenced a significant effect of the season on cow milk FP, whereas Brzozowski and Zdziarski (2005) found that FP was higher in the autumn-winter and lower in spring-summer season.

\section{Conclusions}

In Italy, buffalo breeding plays an important role in the economic and social field. Milk is, and remains, the principle product and is almost all transformed into mozzarella cheese. This cheese, being obtained from milk with a higher fat to protein ratio, results softer, more appetizing and is increasingly more appreciated by consumers.

Due to the increasing request in Italy and for the export to other countries, buffalo milk could be subject to frauds as addition of water to increase the volume. This fraud can be unmasked by monitoring of milk FP. In this context, became fundamental having a valid reference range.

The present study provides the first indication to set a reference range for basic freezing point of buffalo milk.

\section{References}

Ahmad S, Anjum FM, Huma N, Sameen A, Zahoor T, 2013. Composition and physico-chemical characteristics of buffalo milk with particular emphasis on lipids, proteins, minerals, enzymes and vitamins. J Anim Plant Sci 23:62-74.

Ahmad S, Gaucher I, Rousseau F, Beaucher E, Piot M, Grongnet JF, Gaucheron F, 2008. Effects of acidification on physico-chemical characteristics of buffalo milk: A comparison with cow's milk. Food Chem 106:11-7.

Araújo KBS, Rangel AHN, Fonseca FCE, Aguiar EM, Simplício AA, Novaes LP, Júnior DML, 2012. Influence of the year and calving season on production, composition and mozzarella cheese yield of water buffalo in the State of Rio Grande do Norte, Brazil. Ital J Anim Sci 11:87-91.

Bartocci S, Tripaldi C, Terramoccia S, 2002. Characteristics of foodstuffs and diets, and the quanti-qualitative milk parameters of Mediterranean buffaloes bred in Italy using the intensive system an estimate of the nutritional requirements of buffalo herds lactating or dry. Livest Prod Sci 77:45-58.
Brzozowski P, Zdziarski K, 2005. Freezing point of udder-milk in milk-producing cows. Med Weter 61:934-936.

Campanile G, De Filippo C, Di Palo R, Taccone W, Zicarelli L, 1998. Influence of dietary protein on urea levels in blood and milk of buffalo cows. Livest Prod Sci 55:135-43.

European Commission (1992). Council Directive of 16 June 1992 laying down the health rules for the production and placing on the market of raw milk, heattreated milk and milk-based products, 92/46/EEC. Official Journal of the European Union $\mathrm{n} \mathrm{n}^{\circ} \mathrm{L} 268$ of 14/09/1992.

European Parliament and European Council (2013). Regulation of the European Parliament and of the Council of 17 December 2013 establishing a common organisation of the markets in agricultural products and repealing Council Regulations (EEC) $n^{\circ}$ 922/72, (EEC) $n^{\circ}$ 234/79, (EC) $n^{\circ} 1037 / 2001$ and (EC) $n^{\circ}$ $1234 / 2007$. Official Journal of the European Union $\mathrm{n}^{\circ} \mathrm{L} 347$ of 20/12/2013.

FAOSTAT, 2017. Livestock Primary. available form: http:/www.fao.org/faostat/ en/\#data/QL

Henno M, Ots M, Jõudu I, Kaart T, Kärt O, 2008. Factors affecting the freezing point stability of milk from individual cows. Int Dairy J 18:210-5.

Hofi AA, Rifaat ID, Khorshid MA, 1966. Studies on some physicochemical properties of Egyptian buffaloes and cows' milk. Indian J Dairy Sci 19:1137.

IDF Payment systems for ex-farm milk. (2006) Bulletin no. 403 International Dairy Federation, Brussels, Belgium.

Kędzierska-Matysek M, Litwińczuk Z, Florek M, Barłowska J, 2011. The effects of breed and other factors on the composition and freezing point of cow's milk in Poland. Int $\mathrm{J}$ Dairy Technol 64:336-42.

Nascimento CF, Santos PM, Pereira-Filho ER, Rocha FRP, 2017. Recent advances on determination of milk adulterants. Food Chem 221:1232-44.

Pesce A, Salzano C, De Felice A, Garofalo F, Liguori S, De Santo A, Palermo P, Guarino A, 2016. Monitoring the freezing point of buffalo milk. Ital J Food Saf 5:95-7.

Potena A, Bove D, Cocca T, Haubner T, Zicarelli L, 2001. Andamento di alcune componenti del latte di bufala in funzione della distanza dal parto: risultati preliminari. Atti I Congresso Nazionale sull'allevamento del buffalo. 3-5 ottobre 2001, Eboli. pp 231-35. 
Prajapati DB, Kapadiya DB, Jain AK, Mehta BM, Darji VB, Aparnathi KD, 2017. Comparison of Surti goat milk with cow and buffalo milk for physicochemical characteristics, selected processing-related parameters and activity of selected enzymes. Vet World 10:47784.

Radeljevic B, Mikulec N, Zamberlin S̆., Senevirathne PGND, Mangalika ULP, Horvat I, Maletic M, Antunac N, 2012.
The influence of sample preservation and freezing of cow's, goat's and ewe's milk on the freezing point value. Milchwissenschaft 67:169-72.

Slaghuis BA, 2001. The freezing point of authentic and original farm bulk tank milk in The Netherlands. Int Dairy J 11:121-6.

Adikari AMJB, Nayananjalie WAD,
2016. Evaluation of Cow Factors and Milk Composition on Freezing Point Depression of Cow Milk. Int J of Livest Res 6:61-7.

Zagorska J, Ciprovica I, 2013. Evaluation of factors affecting freezing point of milk. Int J Nut Food Eng 7:106-11.

Zicarelli L, 2004. Buffalo milk: its properties, dairy yield and mozzarella production. Vet Res Comm 28:127-35. 